\title{
Design in Spanish Higher Education: Competences and New Technologies
}

\author{
Sheila Gonzalez Mardones \\ Department of Visual Arts and Design, Faculty of Fine Arts, University of Barcelona, Spain
}

Copyright $\mathrm{C} 2019$ by authors, all rights reserved. Authors agree that this article remains permanently open access under the terms of the Creative Commons Attribution License 4.0 International License

\begin{abstract}
In Spain, education in the field of design is not clearly structured and fails to dovetail with current legal and professional reality in terms of the profiles and competences that are offered. This article presents a structured set of competences aimed at undergraduate, university-level, programs that is well-adjusted to the professional accreditation system and establishes a structure and classification that is specific and relevant to this field. This will serve as a starting point for the analysis of the unique characteristics of higher education design programs in the setting of the new paradigm brought about by technological change, considering what new information and communication technologies bring to the process, particularly in online education platforms.
\end{abstract}

Keywords Graphic Design, Competences, Education, Professional Structure, Online Education

\section{Introduction}

In Spain, design as a higher education subject area had to wait until the year 2010, when a full degree program was first offered. Design, which is understood as the discipline that is responsible for the study of visual communication, has been fighting for its place as a profession and as a field of study since its first appearance in Spanish university curricula in 1981 .

A lack of local tradition, technological innovation and the dizzying pace of change in the new information society have relegated design to relative invisibility, compared to other similar project-oriented professions with a longer tradition. In “¿Qué hacen los diseñadores cuando diseñan?” ("What Are Designers Up To When They Design?") Raúl Belluccia stated: Many designers find it unsettling, anxiety-inducing and unsatisfactory when they are forced to classify the work they do; apparently, a mere description of the tasks involved in design isn't enough. They feel compelled to attach to the core of their work poorly defined ethical goals or social commitments or even alleged artistic missions that design and designers would carry encoded in their very DNA. [1]

Who the design professionals are, where they get their training and what their competences are, these are all essential questions in defining this field - and a clear definition is the foundation for a stronger profession and field of study. The existence of a freestanding design degree, separate from Fine Arts programs, has been a decisive moment in the definition of this profession. A clear definition of the competences and knowledge that such a program should be expected to deliver is essential in placing such a degree within the broader educational framework.

\section{Materials and Methods}

The study starts by a qualitative analysis of current curricula of the official design studies offered by Design Universities or Design Schools, booth public and private. At first, the competences were divided by educational level. To define the levels, the study uses the standard professional levels that are accredited by Ministerio de Educación, Cultura y Deporte (Spanish Ministry of Education, Culture and Sport) that lead to different professional qualifications. These levels are defined by the Ministry taking into account the responsibility and competences of the professionals.

This analysis reveals that highest-level competences (MA competences) are taught in university degree programs (BA). Working from this premise, a qualitative comparative study was performed examining all the academic BA curricula offered by universities based in Catalonia (as this is the region with the largest number of programs and the strongest tradition of graphic design within Spain) in order to analyze their fit with current legal and educational frameworks. This study allowed compiling all the competences that the universities associate to graphic design studies and crossing the data with the previous analysis to eliminate those that did not correspond 
to level 3. With that, this article makes a proposal for a coherent and structured set of competences, in line with current professional and legal Spanish regulatory frameworks. The proposed classification is different from the one that is usually used in the universities, that permits a restructuring of current educational systems and a more effective provision of professional training that would be better adjusted to the legal and professional reality that these students will be working in.

\section{Design Education in Spain}

In Spain, there are 6 levels of education and training in the field of design, as can be seen in the table 1. Five of those six levels are directly linked to professional practice, namely levels 1 through 5. The last level refers to $\mathrm{PhD}$ programs, which are oriented to research and teaching.

Each of these levels is expected to produce a degree of competence that will increase and enable students to take on greater responsibility as a higher level is achieved. We define 'competence' as the skills that a student needs to succeed in a specific activity in a specific context, as defined by Mauri, Colomina and Gispert [2]. This lays out a career path from a basic vocational qualification to a much broader, higher-level education that may reach across different fields.

Table 1. Graphic design education in Spain - levels.

\begin{tabular}{|c|c|c|}
\hline Level 6 & PhD programs & Limited availability \\
\hline Level 5 & Master's (MA) & Many options \\
\hline Level 4 & Postgraduate (non-MA) studies & Many options \\
\hline Level 3 & University degrees (BA) & $\begin{array}{c}\text { Design } \\
\text { Audiovisual design } \\
\text { Graphic design }\end{array}$ \\
& Praphic and digital design \\
\hline Level 2 & Postsecondary vocational diplomas & $\begin{array}{c}\text { Audiovisual design } \\
\text { Print design } \\
\text { Interactive design } \\
\text { Advertising art }\end{array}$ \\
\hline Level 1 & Secondary-level & Print shop assistant \\
& vocational qualifications & Interactive design assistant \\
\hline
\end{tabular}

Table 2. Levels of professional responsibility

\begin{tabular}{|l|l|}
\hline Level 1 & Command of a limited set of simple activities in the setting of well-established processes. Limited required knowledge and skills. \\
\hline Level 2 & $\begin{array}{l}\text { Command of a well-defined set of professional activities using adequate instruments and techniques. This work may be done } \\
\text { autonomously within the limits of those techniques. Requires being acquainted with the technical and scientific foundations } \\
\text { underpinning that activity and understanding and being capable of applying that process. }\end{array}$ \\
\hline Level 3 & $\begin{array}{l}\text { Command of a range of professional activities that require a strong grasp of several techniques and the ability to work } \\
\text { aunomously. Involves managing and supervising technical and specialized work. Requires being acquainted with the technical } \\
\text { and scientific foundations behind those activities and being capable of evaluating the factors involved in this process and their } \\
\text { economic implications. }\end{array}$ \\
\hline Level 4 & $\begin{array}{l}\text { Command of a broad range of complex activities. Many different contexts involving technical, scientific, economic and } \\
\text { organizational variables. Responsible for job supervision and resource allocation. Capable of innovating and planning strategies, } \\
\text { developing projects, processes, products and services. }\end{array}$ \\
\hline Level 5 & $\begin{array}{l}\text { Command of a broad range of very complex activities to be performed in a fully independent manner. Many different contexts, } \\
\text { including unpredictable scenarios. Planning strategies and product, process or service design. Responsible for managing and } \\
\text { leading. }\end{array}$ \\
\hline
\end{tabular}

Source: Instituto Nacional de las Cualificaciones Profesionales (Spanish Institute for Professional Qualifications) http://incual.mecd.es
This article focuses on level 3, which we define as contextualization, given the project phases and the level of responsibility within the design process [3].

According to the Spanish "Instituto Nacional de las Cualificaciones Profesionales" (National Institute for Professional Qualifications), which operates within the Spanish Ministry of Education, level 3 of professional qualification is defined as: "Competence in a set of professional activities that require the command of number of techniques and can be performed autonomously. It involves responsibility in the coordination and supervision of specialized and technical work. It also requires a thorough knowledge of the technical and scientific foundations of the process, and of its economic implications." [4]

The table below indicates how this fits into the overall educational structure. This third level differs from the one immediately below it due to the requirement of a capacity to manage and supervise technical and specialized work and knowledge of the underlying technical and scientific foundations in order to evaluate production and potential economical outcomes. This level differs from the level immediately above it since it is only expected to be applicable in one single context, without involving changing contexts or innovation or resource allocation. 


\section{Level 3 Competences. Undergraduate University Degrees}

\subsection{Current State}

Universities classify the competences they strive to develop in students as General or Transversal. The latter term refers to a set of competences defined by Ugarte and Naval [5] as required for the development of critical thinking that will enable graduates to be conscious citizens, capable of independently forming well-informed opinions. At the same time, higher education curricula strive to develop so-called 'Specific' competences, which in this case would include all those skills that are directly involved in the professional practice of design.

In each section, we refer to both intellectual competences and competences linked to participation as defined by Ugarte and Naval [6].

\subsection{Proposal}

This proposal aims to clarify the nature of these competences and match them directly with aspects of professional practice by establishing a classification which deviates significantly from traditional higher education classifications (general, transversal and specific competences), achieving a better fit with real-life needs.

This classification system defines 8 levels that attempt to reflect the interdisciplinary nature of graphic design:

1. Professional context

2. Social, cultural and historical context

3. Communication

4. Discipline foundations

5. Methodology

6. Ethics and sustainability

7. Techniques and technologies

8. Teamwork

This proposal for a classification compares and distills the competences from several curricula, identifying the elements that they have in common, the elements that are unique to some institutions and that fall below or rise above the range of skills required for responsibility level 3: Contextualization.

The conclusion is that competences that are linked to professional settings fall into levels 4 and 5 and therefore do not belong to a university-level undergraduate degree program.

In the second group - Social, cultural and historical context - we find 4 competences covering transversal content referring to the history and culture of design.

1. Knowledge of the overall history of design, art and architecture and its technical evolution.

2. Knowledge, understanding and interpretation of the theoretical framework of design and a strong command of the specific vocabulary of this discipline.
3. Familiarity with the basics of human and social sciences, enabling research as required by the needs of each design project.

4. Understanding the social context of each project and appreciating the design challenges it implies, developing alternative solutions that improve accessibility and inclusion by resorting to cultural, artistic or instrumental approaches in a social responsibility framework.

The third group of competences is essential for graphic design education, given that design is, in fact, communication, so strong communication skills will be the key in the professional development process.

1. Having a strong command of communication (including oral and written expression and comprehension) in a manner that is sensitive to diverse audiences, the environment and the many settings this communication could be taking place in.

2. Having a strong command of specialized professional vocabulary.

3. Being capable of forming carefully thought-through critical opinions.

4. Being able to communicate the results of a design process in an effective, intelligible and attractive manner and write professional reports.

5. Being capable of visualizing and communicating information: effective use of graphic presentation, information design and infographic techniques.

6. Having a strong command of aesthetic and symbolic languages, and of the language of design itself, in order to align a project's communication goals with users' real-life perceptions.

The fourth group covers the foundations of design and includes morphology, physics, hierarchy and visual ergonomics. This is the most specific group and has the greatest number of entries.

1. Having a strong knowledge of (and the capacity to apply) the aesthetic foundations of design (shape or morphology, figure, structure, color, space, volume, tectonics, typography and composition).

2. Having a good command of the ways that shapes, volumes and sections can be represented: basic descriptive geometry.

3. Having a good command of the application of elementary physical principles in a mathematical setting.

4. Knowing and being capable of applying the relevant ergonomic and anthropometric factors in a design project. Knowledge of the physiology of visual perception and its implications for communication: visual ergonomics.

5. Knowledge of the foundations of usability, accessibility and universally accessible design.

6. Knowledge of the rules of typography: characters, alphabets, letter architecture, etc. as well as the technological and conceptual guidelines for typography design and use.

7. Knowledge of the history of typography and printing 
and the role that typography has played in the evolution of graphic design and publishing.

8. Knowing how to structure and create hierarchies of information.

9. Being aware of symbolic values and how they work: knowledge of the semiotic processes that operate in products, systems, services, and other forms of communication. Having command of the relevant communication codes with an awareness of both denotation and connotation in order to communicate effectively.

The fifth group covers competences related to the creation, use and implementation of design processes:

1. Having the ability to identify problems that can be addressed through design and present them as such.

2. Being able to design, i.e. develop a coherent design process that involves the ability to adequately provide a body of specifications and requirements, which involves selecting information sources, analyzing data and distilling it into a formal presentation, applying this knowledge to practical development, managing with a project-wide vision, proposing and defending a design approach and taking it through to the production and manufacturing stage.

3. Having the ability to present a design concept and apply coherent criteria in the decision-making process and in the formal project proposal stage for simple projects.

4. Being capable of evaluating outcomes.

5. Being capable of developing a personal work methodology.

The sixth group includes competences related to a designer's ethical stance when facing a project and the importance of sustainability and social inclusiveness.

1. Displaying values that are aligned with professional ethics.

2. Being capable of appreciating a product's environmental impact. Being mindful of each material's properties and behavior and using them in socially and environmentally responsible ways.

3. Displaying open, respectful, inclusive, and responsible values that are sensitive to diverse opinions. Being capable of sustaining an independent and critical position while taking full responsibility for one's ethical stance.

The seventh group includes competences that are linked to the knowledge and mastery of technologies that are frequently used in professional projects:

1. Strong command of digital technology and computer-based tools.

2. Knowledge and command of the full array of technological tools and techniques involved in the design process: specific software, conventional and digital presentation systems, model and prototype construction, photography, video, animation and illustration as well as other specific procedures and techniques.

3. Basic familiarity with construction, production and materials technologies.

4. Being capable of choosing the materials and the procedures for construction or transformation, as needed, with an awareness of relative qualities and costs.

5. Having provable knowledge and skills in the digital and audiovisual production domains and a good command of tools required for creation and production.

6. Problem-solving using the techniques, procedures, tools and materials of visual arts, design and crafts.

The last group includes one last competence related to human resources and teamwork:

1. Teamwork skills. Have the ability to work with other professionals and contribute to a shared project.

\section{New Digital Information and Communication Technologies}

We are currently facing a transition towards a post-industrial society: information, knowledge and education are still often rooted in the previous paradigm, with approaches that made sense in an industrial setting but that now feel simplistic and rigid, as Fernando Hernández points out [7]. Design is a profession that is inextricably linked to media and technology. It is also a profession that increasingly relies on teamwork. Vilar suggests that growing social complexity has forced us to examine the boundaries of what we define as science and has led to a transition from single-discipline tactics to transdisciplinary strategies and, finally, interdisciplinary approaches. [8] This is the current situation in design according to Ana Herrera - it is time to stop designing on our own and develop a strong exchange with other disciplines [9].

Jesús Salinas [10] names a series of changes that have recently affected education:

1. Major changes in higher education (new European Higher Education regulation)

2. Change brought about by the digital revolution

3. Changes in knowledge (how it is generated, managed and distributed)

4. Changes in the profile of enrolled students

These changes are definitely linked to the paradigm shift that has been seen in design education since 2010: specific university degree programs, a technological revolution that has wiped out entire professions (prepress experts, for example, have become obsolete in the era of Photoshop). Approaches to education cannot be short-sighted - a fully-equipped professional will need to know how to 
navigate interdisciplinary projects and successfully engage in teamwork with large, diverse networks of professionals. Finally, it is increasingly frequent to find that students must deal not only with their education, but also with a job and a family.

In such an environment, a traditional inward-looking education that focuses only on transmitting facts but doesn't bring about cooperation and teamwork will be found severely wanting and in need of change in order to adapt.

Distance learning using online educational platforms emerges as a very promising alterative in the field of design education.

Removing geographical and schedule-related barriers is major progress for education. The fact that students can participate in the learning process from any location at any time and share experiences with people living in many different cultures brings about valuable exchanges, interdisciplinary work and social and cultural exchanges, as stated by Herrera.

Graphic design and visual communication is a professional field where digital information and communication technologies have become the backbone of the work process. Distance education and professional practice share the same operative language, and this underlies the fact that online education equips students not only with the skills which will be needed for professional practice, but also with a good command of the communication and information tools that such a profession will require.

We can describe graphic design as a project-oriented discipline. Teaching in any such project-oriented discipline can never be one-way. Instructors who only fulfill the role of transmitting knowledge will never be effective because there is never a single correct solution or answer to a design problem. Design can never be learned by rote. Faculty will have to act as mediators and facilitators, not as someone who relays information. Jerónimo and Andrade state that in online education, instructors are "the essential intermediary between knowledge and students' learning processes" [11] taking knowledge from implicit to explicit form [12]. This approach draws on Honnecutt's philosophy of knowledge management [13] which stresses the importance of timely delivery of the right information to the right person, ensuring that the right tools are available to work with that information. Students enrolled in university-level design programs must learn to engage in critical and independent thought. Salmerón, Rodríguez and Gutiérrez [14] make it quite clear that new technologies and collaborative approaches to teaching are instrumental in successfully teaching such skills, given the fact that they bring about social interaction and the cognitive changes such interactions will unleash.

If we keep in mind the significant changes that online education brings about, according to Fombona and Mampaso (cit. González, Salgado and Fambona) [15]:
- Visual and audiovisual communication overtake verbal communication in usage and importance.

- Transition from printed page to computer screen as data presentation tools.

- Information design that does away with the linear nature of text - which will become hypertext. .

- Students as content creators, as well as consumers.

We will realize that we are discussing questions that are very present in the field of graphic design, given that the very essence of this field is visual communication. A computer screen is the daily tool. Hyperconnected and interdisciplinary knowledge is essential to resolve design tasks. Students will have to develop their own way of thinking and successfully completing projects.

We can therefore state that there is a natural connection between the nature of the tools that are used in online education and the tools that are used in design and this connection will enhance the learning process.

The fact that this learning process takes place in an online environment can be a significant advantage in the process of acquiring the previously stated competences. One of the primary groups of competences covers communication. A virtual communication setting enhances the use of diverse communication tools and will be more enriching as it will compel students to express themselves using a range of different tools and this will foster greater agility and the capacity to adjust to new settings. The educational process will include formal written communication, visual communication, oral communication, etc. The fact that instructors have the ability to record and monitor all those communications will enable them to accurately assess progress in each of those settings. Students won't just study these skills as tools for professional practice but will take full ownership of them and bring them into their daily life, ensuring they will be able to use them in real life settings, and not just have another line on their CVs.

The opportunity of being able to enroll in a program that doesn't impose geographical or schedule constraints also improves social skills and cultural sensitivity as it creates groups of students from different countries and social and cultural backgrounds. This enriches design projects and equips participants with assets that will prove valuable in their careers. Good teamwork skills and open-minded, lateral, thinking have always been the hallmark of the best graphic design professionals.

As for digital technology skills, the fact that they are the backbone of the learning environment is an excellent opportunity to strengthen those skills, ensuring they will be second nature of the students and not just something they have studied as a professional skill. Working in an online setting fosters a strong familiarity with computer-driven tools, software and audiovisual media.

Online education also provides opportunities for new ways of approaching assessment, as Miguel Zapata [16] points out that virtual educational settings should 
complement or replace traditional evaluation methods using descriptive or conceptual tasks (exams or papers) with other procedures that offer something closer to real-world performance, such as case studies that involve research, project development, etc. all with ongoing instructor monitoring. Online design education programs resort to precisely the type of assessment task that Zapata recommends. Online learning environments provide precisely the powerful tools that can allow instructors to follow each student's progress closely. This set of tools and the specific online educational approaches can support mastering skills related to methodology, human resource management and teamwork.

\section{Conclusions}

Currently in Spain, there is a clear lack of structure in the competences of the BA design training programs, which does not correspond to the legal structure of professional competences linked to responsibilities established by the Ministry of Education.

University-level design education is currently being actively developed. A clear set of skill-development goals that dovetail with current legal and professional structures and were added to new options offered by online education, have the potential to bring about a watershed moment in this development process. A clear set of educational and skill-development goals can benefit from the innovative potential of digital technology. Innovation needs to improve on traditional classroom-based education's outcomes in order to produce real progress. A strong awareness of new media's specific nature and potential can enable stronger development of competences that were difficult to cultivate in traditional settings.

The role of faculty in this change is essential as they must embrace their new role as knowledge creation facilitators, instead of acting as knowledge transmitters, as had traditionally been the case. They need to have clear professional responsibility stratification and teach within that premise. This change is the key, as a designer must be capable of generating her own knowledge given that professional environments change constantly. In design, there is never a single solution to a given problem.

\section{REFERENCES}

[1] T. Belluccia, ¿Qué hacen los diseñadores cuando diseñan?; en www.foroalfa.org; 2007 Available: https://foroalfa.org/articulos/que-hacen-los-disenadores-cu ando-disenan. Silver Burdett Press, Londyn, 1986.

[2] T. Mauri, R., Colomina, R. y I. Gispert. Diseño de propuestas docentes con TIC para la enseñanza de la autorregulación en la Educación Superior. Revista de Educación (348), 2009.
[3] S. González-Mardones. El diseño gráfico y sus profesionales. Retos y definiciones. Universidad de Barcelona. Available: http://www.tesisenred.net/handle/10803/373908., 2016.

[4] Ministerio de educación y formación profesional. Available: http://incual.mecd.es/estructura.

[5] C. Ugarte y C. Naval. Desarrollo de competencias profesionales en la educación superior. Un caso docente concreto. Revista Electrónica de Investigación Educativa [Número Especial]. Available:

http://redie.uabc.mx/contenido/NumEsp2/contenido-ugarte .html, 2010.

[6] C. Ugarte. y C. Naval. Desarrollo de competencias profesionales en la educación superior. Un caso docente concreto. Revista Electrónica de Investigación Educativa [Número Especial]. Available:

http://redie.uabc.mx/contenido/NumEsp2/contenido-ugarte .html, 2010.

[7] F. Hernández. Los proyectos de trabajo: la necesidad de nuevas competencias para nuevas formas de racionalidad, Educar 26, España, 2000.

[8] P. Vilar. Pensar históricamente, Crítica, Barcelona, 1997.

[9] A. Herrera. Actualización de una duda; en A. Calvera, (ed.); Arte? Diseño, Gustavo Gili: Barcelona, 2003.

[10] J. Salinas. Innovación docente y uso de las TIC en la enseñanza universitaria. RUSC. Universities and Knowledge Society Journal [en línea] 2004, 1 (Septiembre-Noviembre) : Available:

$<$ http://www.redalyc.org/articulo.oa?id=78011256006> ISSN, 2018.

[11] J. Montes, J. A., L. C. Andrade Cortes y A. Robles Melgarejo (2011): "El diseno educativo en los mundos virtuales. La curva de aprendizaje inmersito". Revista Icono14, Año 9, $\mathrm{n}^{\mathrm{o}} 2$ 2. pp. 2138. Available: https://icono14.net/ojs/index.php/icono14/article/view/, 2018.

[12] J. Swan, M. Robertson y S. Newell. Gestión del conocimiento: el Factor Humano. Editorial Thomson, Madrid, España, pp. 215-233, 2002.

[13] J. Honeycutt. Así es la Gestión del Conocimiento. Mcgraw-Hill/Interamericana de España, S.A. 1ra Edición. España. Vol. 1, p. 16. 2001. ISBN: 9788448129118, 2018.

[14] S. Honorio, S. Rodríguez y C. Gutiérrez. Metodologías que optimizan la comunicación en entornos de aprendizaje virtual. Comunicar [en línea] 2010, XVII Available: $<\mathrm{http}$ //www.redalyc.org/articulo.oa?id=15812481019> ISSN 1134-3478, 2018.

[15] M. Gonzalez, C. Salgado y J. Fambona, J., Competencias didácticas en cursos online de posgrado universitario. Estudios sobre el Mensaje Periodístico Vol. 18 Núm. especial octubre (2012) 443453 Available: http://dx.doi.org/10.5209/rev_ESMP.2012.v18.40999 ISSN: 11341629, 2012.

[16] Zapata, M., Evaluación de competencias en entornos virtuales de aprendizaje y docencia universitaria. RED. Revista de Educación a Distancia. Sección de Docencia Universitaria en la Sociedad del Conocimiento. $\mathrm{N}^{\mathrm{o}} 1$ Available: http://www.um.es/ead/reddusc/1, 2108. 